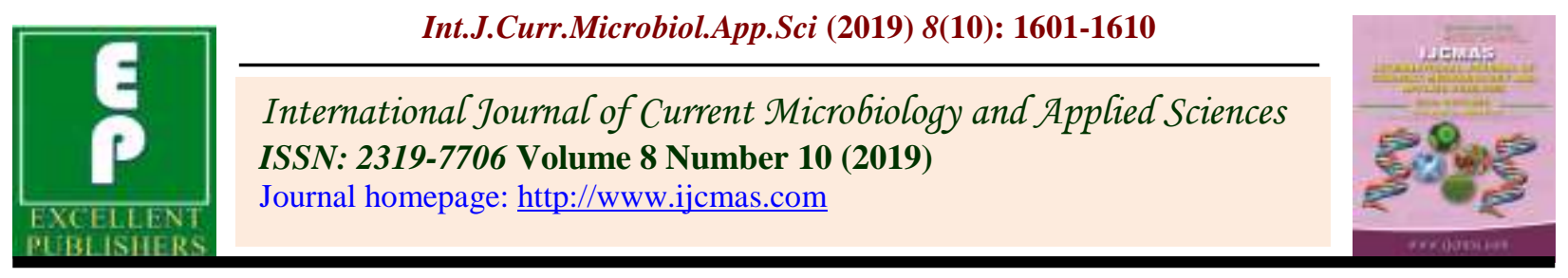

Original Research Article

https://doi.org/10.20546/ijcmas.2019.810.187

\title{
Effect of Different Doses of Nitrogen and Sulphur on Growth and Yield of Garlic
}

\author{
Devesh Tiwari ${ }^{1}$, Ajay kumar Gautam ${ }^{1 *}$, Rohit Kumar ${ }^{1}$ and Sharad Sachan ${ }^{2}$ \\ ${ }^{1}$ Department of Agriculture Sciences, Bhagwant University, Ajmer Rajasthan, India \\ ${ }^{2}$ Department of Agriculture, LPU, Punjab, India \\ *Corresponding author
}

\begin{tabular}{|l|}
\hline Ke y w o r d s \\
Garlic, Sulphur, \\
Nitrogen, Levels, \\
Growth, Yield \\
\hline Article Info \\
\hline $\begin{array}{l}\text { Accepted: } \\
\text { 12 September } 2019 \\
\text { Available Online: } \\
\text { 10 October } 2019\end{array}$ \\
\hline
\end{tabular}

\section{A B S T R A C T}

An experiment was carried out in the Department of Vegetable Science, Kalyanpur, Chandra Shekhar Azad University of Agriculture and Technology, Kanpur, during the Rabi season, 2010-2011. The Geographically location, Kanpur is situated in the Gangetic alluvial belt of central Utter Pradesh and located between $25^{\circ} 26^{\prime}$ to $26^{\circ} 58^{\prime}$ north latitude and $79^{\circ} 31^{\prime}$ to $80^{\circ} 34^{\prime}$ ' east magnitude at an elevation of 127.00 meters above mean sea level. The treatment consists four levels of sulphur $(0,20,40,60 \mathrm{~kg}$ $\left.\mathrm{ha}^{-1}\right)$ and four level of nitrogen $(0,75,100,125 \mathrm{~kg} / \mathrm{hac}$.). The experiment was laid in a randomized block design with three replications. On the basis of one year field experimentation with the graded doses of Nitrogen and Sulphur applied to Garlic crop variety Gujrat-50. It may be concluded that application of $100 \mathrm{Kg}$ nitrogen and $40 \mathrm{Kg}$ Sulphur per hectare gain best results for all the pre harvest attributes like plant height, number of leaves and post harvest like yield attributes and produced significantly highest yield of $74.68 \mathrm{q}$ and $73.34 \mathrm{q}$ per hectare respectively.

\section{Introduction}

India is the "Vegetable basket" of the world. Vegetables play an important role in traditional cropping system to make it more remunerative. The growing of vegetables is particularly suited for small and marginal farmers because these farming families can earn more from limited holding by intensive vegetable cultivation. Vegetables are 4-8 times more remunerative than cereals. Garlic (Allium sativum Linn) is the second most widely cultivated bulb crop after onion and belongs to the family Amaryllidaceae (Alliaceae). It has been recognized as a valuable spice and condiment throughout India. It is a frost hardy bulbous, erect annual herb of 30-100 $\mathrm{cm}$ in height with narrow flat 
leaves and bears small white flowers and bulbils (Janick 1979). A compound bulb consists of 6-35 smaller bulbils or segments called "cloves" which are formed from auxiliary bulbs of the young foliage leaves and is surrounded by a thin white or pinkish papery sheath.

Since the India is the larger exporter of garlic foreign exchange. Productivity could be increased by use of suitable varieties, balanced nutrition, need based agronomic practices. Among the many constraints for low production in garlic, imbalanced nutrition is the main limiting factor. Improving productivity and quality of crop, soil nutrient management plays a significant role (Zhou et al., 2005). Sulphur and nitrogen has been recognized major plant nutrient. Sulphur and nitrogen deficiency is increasing in Indian soils at a faster rate and this has adversely affect the crop production even though crop is applied with recommended dose of $\mathrm{N}, \mathrm{P}, \mathrm{K}$ fertilizers garlic is a sulphur and nitrogen loving plant and the requirement is high for its proper growth and yield. Sulphur is recognized as an important nutrient for higher yield and better grotwth of onion bulbs (Thippeswamy 1993, Tripathy et al., 2013). Severe sulphur deficiency during bulb development has detrimental effect on an alkaloid allylpropyl disulphide, in which sulphur is the prime constituent while nitrogen deficiency effect on growth of plants and bulb also. The balance dose of nitrogen and Sulphur application not only improves the bulb yield, size and number of cloves, pungency, flavors other quality parameters. Zaman et al., 2011 reported that application of $150 \mathrm{~kg} \mathrm{~N}$ ha-1 produced a good yield of garlic. These besides imparting resistance against pests and diseases (Jaggi and Dixit 1999; Magray et al., 2017). Sulphur is essential for building up amino acids, which are building blocks for essential proteins in plants while nitrogen is essential for vegetative growth and bulb development in garlic (Anwar et al., 2001).Nitrogen and Sulphur deficiency in Indian soils becomes more prevalent due to extensive use of sulphur free fertilizers and unbalanced doses of nitrogen. No nitrogen and sulphur application in deficient soils has often resulted in low yield of garlic. Keeping in view the significance of nitrogen and sulphur in the production of garlic crop. In this paper we discuss about different doses of nitrogen and sulphur on growth and yield of garlic.

There are some specific Review of the Related work:

Bertoni, et al., (1992), in greenhouse experiments on Garlic cv. Messidrome plants grown in pots with drip fertigation, root DW and leaf DW began to decline after the last leaf appeared i.e. in the middle of the bulb growth period. Depriving plants of $\mathrm{N}$ at the beginning of bulb growth accelerated and increased the redistribution of organic $\mathrm{N}$ from leaves and roots to the bulbs. Bulb weight was little affected. A supply of $\mathrm{N}$ increased bulb growth and quality until the beginning of senescence but maintaining it beyond this time was slightly detrimental.

Lima, et al., (2008), two experiments were carried out, one in a protected environment and another in the field, aiming to evaluate the effect of nitrogen doses on yield and commercial characteristics in the vernalized Garlic culture, Roxo Perola Cacador cv. A randomized complete block design was adopted, with seven nitrogen doses $(0,20,40$, $60,120,240$, and $360 \mathrm{~kg} \mathrm{ha}^{-1}$ ) and four replications. In the experiment under protected environment there was no incidence of secondary growth plants and the total production of bulbs was influenced by nitrogen doses: the highest production resulted from the $150 \mathrm{Kg} \mathrm{ha}^{-1}$ dose of nitrogen. Most of the bulbs were classified between 3 and 4 , reaching a maximum diameter of $42 \mathrm{~mm}$. 
Wang Pu Shi and Nie (2010), the field experiment was conducted to study the effect of sulphur fertilizer using Garlic plant height, stem diameter, leaf area per plant, rate of rust diseased plant, yield of the bulb and the flower stalk of Garlic by use of the Xinjiang White Garlic as material. Result: The result showed that sulphur fertilizer could accelerate the Garlic's growth and development in Xinjiang Aheqi Garlic area, increase Garlic plant height, the stem diameter and the leaf area per plant, enhance the capacity of rust resistance, increase yield of the bulb and the flower stalk of Garlic. It is better that the application of sulphur fertilizer was $12 \mathrm{~kg} / 667 \mathrm{~m}^{2}$. Conclusion: The yield of the Garlic was increased with the increasing of sulphur fertilizer. However, when the sulphur was exceeded by $12 \mathrm{~kg} / 667 \mathrm{~m}^{2}$, the yield was decreased.

ZhongLiang and ZiKun (2010), effects of different sulphur level on photosynthetic characteristics, fresh weight and qualities of Garlic were studied by nutrient solution. The results showed when sulphur content was 2.25 mmol. $\mathrm{L}^{-1}$, the photosynthetic parameter $\left(P_{\mathrm{n}}\right.$, $\left.G_{\mathrm{s}}, E\right)$, photosynthetic pigment contents in Garlic leaf and the fresh weight of bulb were higher. Higher content of sulphur $(3.75 \mathrm{mmol}$. $\mathrm{L}^{-1}$ ) increased the contents of soluble protein in bulb. At a certain range of sulphur concentrations, with the increase in sulphur level, the Garlic branching index decreased and then had no significant change with the increase of sulphur level.

Ershadi, et al., (2010), Nitrogen plays an important role in growth, yield and quality of crops. Garlic (Allium sativum L.) is an important vegetable in Iran and all over the world. Pungency, as an important character in Garlic, is due to sulphur compounds like Alliine. In this study, the effect of two fertilizers (urea and ammonium sulphate) in five levels of Nitrogen (100, 150, 200, 250 and $300 \mathrm{~kg} \mathrm{~N} \mathrm{ha}^{-1}$ ) was studied on yield, Pungency and Nitrate accumulation of Garlic cv. The highest yield $\left(16620 \mathrm{~kg} \mathrm{ha}^{-1}\right)$ and lowest yield (11530 kg ha ${ }^{-1}$ ) were observed with 200 and $300 \mathrm{~kg} \mathrm{~N} \mathrm{ha}^{-1}$, respectively. According to the results obtained ammonium sulfate in $200 \mathrm{~kg} \mathrm{~N}^{-1}$ level was the best treatment to access high yield with good pungency.

Singh and Singh, (2010), an investigation was carried out for three spacing, i.e. $10 \mathrm{~cm} \times 10$ $\mathrm{cm}, 15 \mathrm{~cm} \mathrm{x} 8 \mathrm{~cm}$ and $15 \mathrm{~cm} \mathrm{x} 10 \mathrm{~cm}$ and four level of nitrogen i.e. 50, 75, 100 and $125 \mathrm{~kg}$ $\mathrm{ha}^{-1}$ in form of urea in Garlic variety Yamuna safed (G-1). The highest yield 98.23 $\mathrm{q} \mathrm{ha}^{-1}$ may be obtained by sowing the cloves at closer spacing $10 \mathrm{~cm} \times 10 \mathrm{~cm}$ and applying highest dose of nitrogen $125 \mathrm{~kg} \mathrm{ha}^{-1}$.

\section{Materials and Methods}

Soil of the experimental plot was clay $14.10 \%$ sand $62.40 \%$, silt $22.00 \%$ having $\mathrm{PH}$ of 6.21 , Soil organic Carbon $0.50 \%$, Electrical conductivity $0.25 \mathrm{dsm}^{-1}$, total nitrogen $0.52 \%$,total phosphoras $0.080 \%$,total potash, $0.054 \%$, Boron(ppm) $0.20 \%$ and Suphur (ppm) $0.27 \%$ respectively. There are sixteen treatment consists four levels of sulphur $\left(0,20,40,60 \mathrm{~kg} \mathrm{ha}^{-1}\right)$ and four levels of nitrogen $(0,75,100,125)$.

The experiment was laid in a randomized block design with three replications. The different levels of nitrogen were applied in different treatments, the half dose of nitrogen were applied at the time of planting and second half dose of nitrogen were applied after 45 days of planting. Nitrogen, phosphorus and potassium were applied through Urea, DAP and Murate of Potash (MOP) respectively.

Farmyard manure of seven weeks old was tranplanted @20 t per hac. at a spacing of 
$15 \times 10 \mathrm{cms}$ in plots of $3.0 \times 2.00 \mathrm{~m}$ size in the last week of November during 201011.Recommended package of practices was adopted to raise a healthy garlic crop. The crop was harvested in last second of April.

The Observations on growth and yield, were recorded, using standard procedures. The recorded data was subjected to statistical analysis as per the procedure suggested by Panse and Sukhatame (1978).

\section{Results and Discussion}

The yield is the cumulative result of many factors like agro-climatic conditions available for growth and development of crop, plant height, number of leaves, total yield of Garlic.

Hore and Chanchan (2014) who reported that application of nitrogen and silphur increased the total bulb yield of garlic. The monthly weather conditions prevailing during the experimental period are given in the table 3.1 and fig 3.1 .

The results and discussion are given below with specific points:

\section{Growth and yield parameters}

The results of the plant growth and yield have been presented systematically in various tables. Emphasis has been given on the statistical analysis in order to compare one treatment to another. Important data have also been represented in the table with graphical form to provide better understanding of important trends wherever necessary.

\section{Pre-harvest observations}

\section{Plant height (cm)}

The data of height of plant taken at maturity time were tabulated and analyzed statistically.
The results have been produced in Table 4.1. The plant height of Garlic was significantly affected from various level of nitrogen. Application of $100 \mathrm{~kg} / \mathrm{ha}$ produced significantly highest plant height $(51.05 \mathrm{~cm})$.

Sulphur levels influenced plant height significantly and produced highest plant height under $40 \mathrm{~kg}$ sulphur/ha $(54.96 \mathrm{~cm})$.

The increase in growth characters with the application of sulphur might be due to its use in the manufacture of chlorophyll (Nagaich $e t$ al., 1999). The results are in conformity with those of Farooqui et al., (2011).

\section{Number of Leaves per Plant}

Observation regarding the number of leaves per plant of Garlic was recorded at maturity time. The main effect of sulphur and nitrogen were also depicted in fig. 4.3.

Data indicated that the number of leaves per plant of Garlic was significantly affected from various level of nitrogen $(0,75,100$ and 125 $\mathrm{kg} / \mathrm{ha}$ ). Application of $100 \mathrm{~kg} / \mathrm{ha}$ nitrogen produced significantly maximum number of leaves (8.86),

Sulphur levels for the different treatments produced significant and maximum number of leaves of Garlic leaves was recorded under the $40 \mathrm{~kg}$ sulphur/ha (9.68).

\section{Yield per hectare (q)}

Observation recording the yield per hectare of Garlic bulb was recorded after maturity crop. The main effect of nitrogen and sulphur were also shown in fig. 4.3.1.

The yield was found maximum under $100 \mathrm{~kg}$ nitrogen/ha (74.68 q) followed by 125 (71.18 q), $75(65.01 \mathrm{q})$ and $0 \mathrm{~kg}$ nitrogen/ha (54.34 q). 
Table.1 Average monthly observed weather parameters during 2010-2011, Kanpur

\begin{tabular}{|c|c|c|c|c|}
\hline Months & $\begin{array}{c}\text { Temp. } \\
\text { Max. }\left({ }^{\circ} \mathbf{c}\right)\end{array}$ & $\begin{array}{c}\text { Temp. } \\
\text { Min. }\left({ }^{\circ} \mathbf{c}\right)\end{array}$ & $\begin{array}{c}\text { Relative } \\
\text { Humidity } \\
(\boldsymbol{\%})\end{array}$ & Total Rainfall (mm) \\
\hline November & 28.20 & 15.20 & 74.50 & 0.00 \\
\hline December & 23.80 & 8.20 & 55.50 & 0.00 \\
\hline January & 24.80 & 6.80 & 68.50 & 0.00 \\
\hline February & 24.00 & 12.30 & 73.00 & 0.00 \\
\hline March & 33.40 & 15.80 & 58.00 & 0.00 \\
\hline April & 36.60 & 20.80 & 38.00 & 0.00 \\
\hline
\end{tabular}

Source:- Department of Agronomy, C.S.A Kanpur (U.P.)

Table.2 Mechanical and chemical analysis of soil

\begin{tabular}{|c|c|}
\hline Physic-chemical characteristics & Contents \\
\hline Physical analysis & \\
\hline Sand & $62.40 \%$ \\
\hline Silt & $22.00 \%$ \\
\hline Clay & $14.10 \%$ \\
\hline Chemical analysis & \\
\hline pH (Scale) & $5.5-7.0$ \\
\hline Organic carbon & $0.50 \%$ \\
\hline Total nitrogen & $0.52 \%$ \\
\hline Total phosphorus & $0.080 \%$ \\
\hline Total potash & $0.054 \%$ \\
\hline Electric conductivity (mmhos $\mathbf{c m}^{-\mathbf{1}}$ ) & $0.25 \%$ \\
\hline Boron (ppm) & $0.20 \%$ \\
\hline Sulphur (ppm) & $0.27 \%$ \\
\hline
\end{tabular}

Table.3 Effect of nitrogen and sulphur on the average height of plant $(\mathrm{cm})$ of garlic

\begin{tabular}{|c|c|c|}
\hline Symbols & Treatment & Plant height $(\mathbf{c m})$ \\
\hline & Nitrogen levels (kg/ha) & \\
\hline $\mathbf{N}_{\mathbf{1}}$ & 0 & 47.65 \\
\hline $\mathbf{N}_{\mathbf{2}}$ & 75 & 48.61 \\
\hline $\mathbf{N}_{\mathbf{3}}$ & 100 & 51.05 \\
\hline $\mathbf{N}_{\mathbf{4}}$ & 125 & 49.94 \\
\hline & CD at 5\% & 4.64 \\
\hline & Sulphur level (kg/ha) & \\
\hline $\mathbf{S}_{\mathbf{1}}$ & 0 & 43.20 \\
\hline $\mathbf{S}_{\mathbf{2}}$ & 20 & 46.39 \\
\hline $\mathbf{S}_{\mathbf{3}}$ & 40 & 54.96 \\
\hline $\mathbf{S}_{\mathbf{4}}$ & 60 & 52.70 \\
\hline & CD at 5\% & 2.32 \\
\hline
\end{tabular}


Table.4 Effect of nitrogen and sulphur on number of leaves per plant of garlic

\begin{tabular}{|c|c|c|}
\hline Symbols & Treatment & Number of Leaves \\
\hline $\mathbf{N}_{\mathbf{1}}$ & Nitrogen levels $(\mathrm{kg} / \mathrm{ha})$ & \\
\hline $\mathbf{N}_{\mathbf{2}}$ & 0 & 8.14 \\
\hline $\mathbf{N}_{\mathbf{3}}$ & 75 & 8.50 \\
\hline $\mathbf{N}_{\mathbf{4}}$ & 100 & 8.86 \\
\hline & 125 & 8.72 \\
\hline & $\mathrm{CD}$ at $5 \%$ & 0.60 \\
\hline $\mathbf{S}_{\mathbf{1}}$ & Sulphur level $(\mathrm{kg} / \mathrm{ha})$ & 7.37 \\
\hline $\mathbf{S}_{\mathbf{2}}$ & 0 & 8.08 \\
\hline $\mathbf{S}_{\mathbf{3}}$ & 20 & 9.68 \\
\hline $\mathbf{S}_{\mathbf{4}}$ & 40 & 9.09 \\
\hline & 60 & 0.60 \\
\hline
\end{tabular}

Table.5 Effect of nitrogen and sulphur on yield per hectare (q)

\begin{tabular}{|c|c|c|}
\hline Symbols & Treatment & Yield Per Hectare (q) \\
\hline $\mathbf{N}_{\mathbf{1}}$ & Nitrogen levels (kg/ha) & \\
\hline $\mathbf{N}_{\mathbf{2}}$ & 0 & 54.34 \\
\hline $\mathbf{N}_{\mathbf{3}}$ & 75 & 65.01 \\
\hline $\mathbf{N}_{\mathbf{4}}$ & 100 & 74.68 \\
\hline & 125 & 71.18 \\
\hline & CD at 5\% & 9.81 \\
\hline $\mathbf{S}_{\mathbf{1}}$ & Sulphur levels (kg/ha) \\
\hline $\mathbf{S}_{\mathbf{2}}$ & 0 & 56.01 \\
\hline $\mathbf{S}_{\mathbf{3}}$ & 20 & 64.51 \\
\hline $\mathbf{S}_{\mathbf{4}}$ & 40 & 73.34 \\
\hline & 60 & 71.34 \\
\hline
\end{tabular}


Fig.1 Initial status of experimental field with respect to available N, P, K, S, OC and soil pH

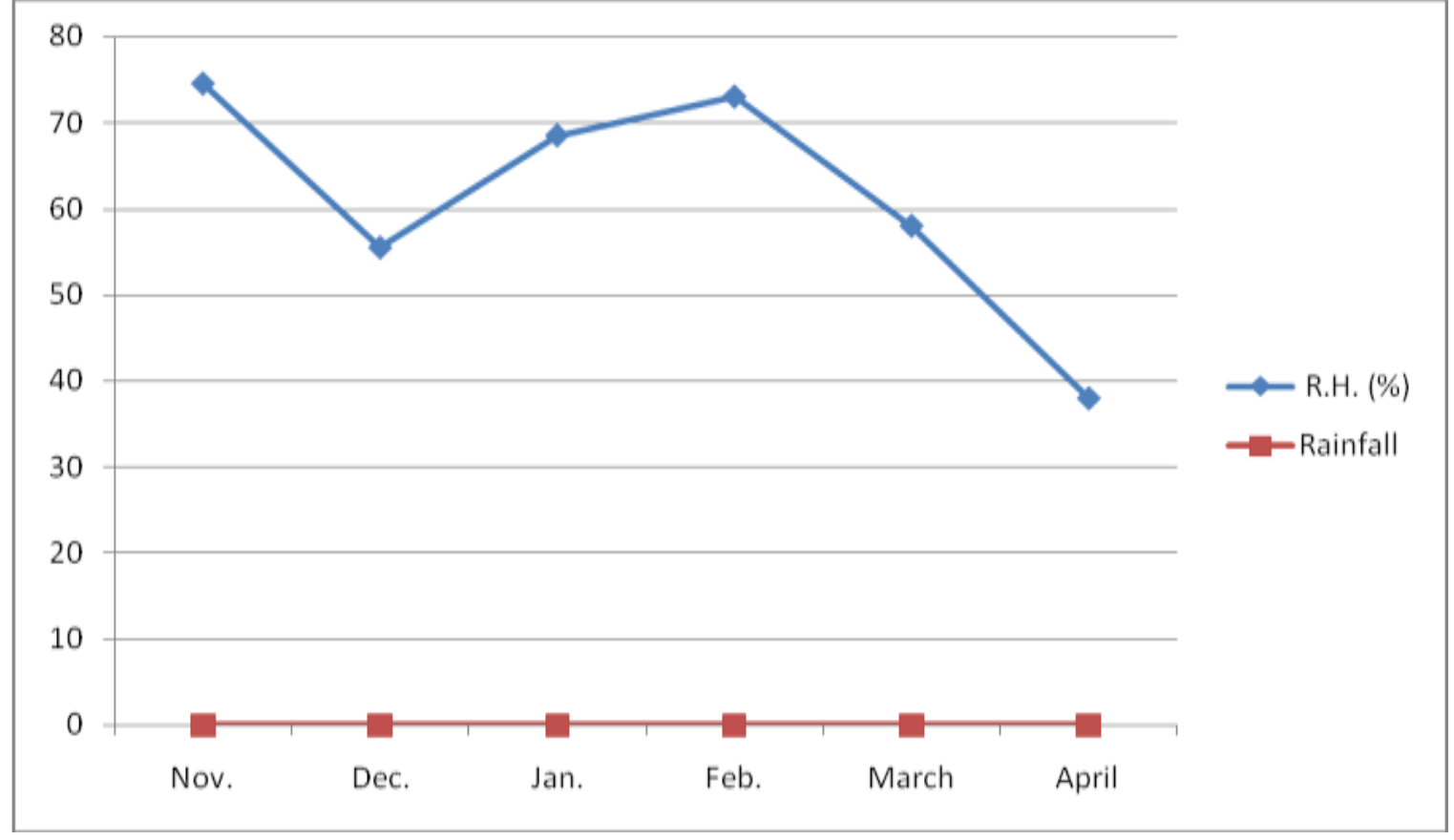

Fig.2 Effect of nitrogen and sulphur on the average plant height $(\mathrm{cm})$

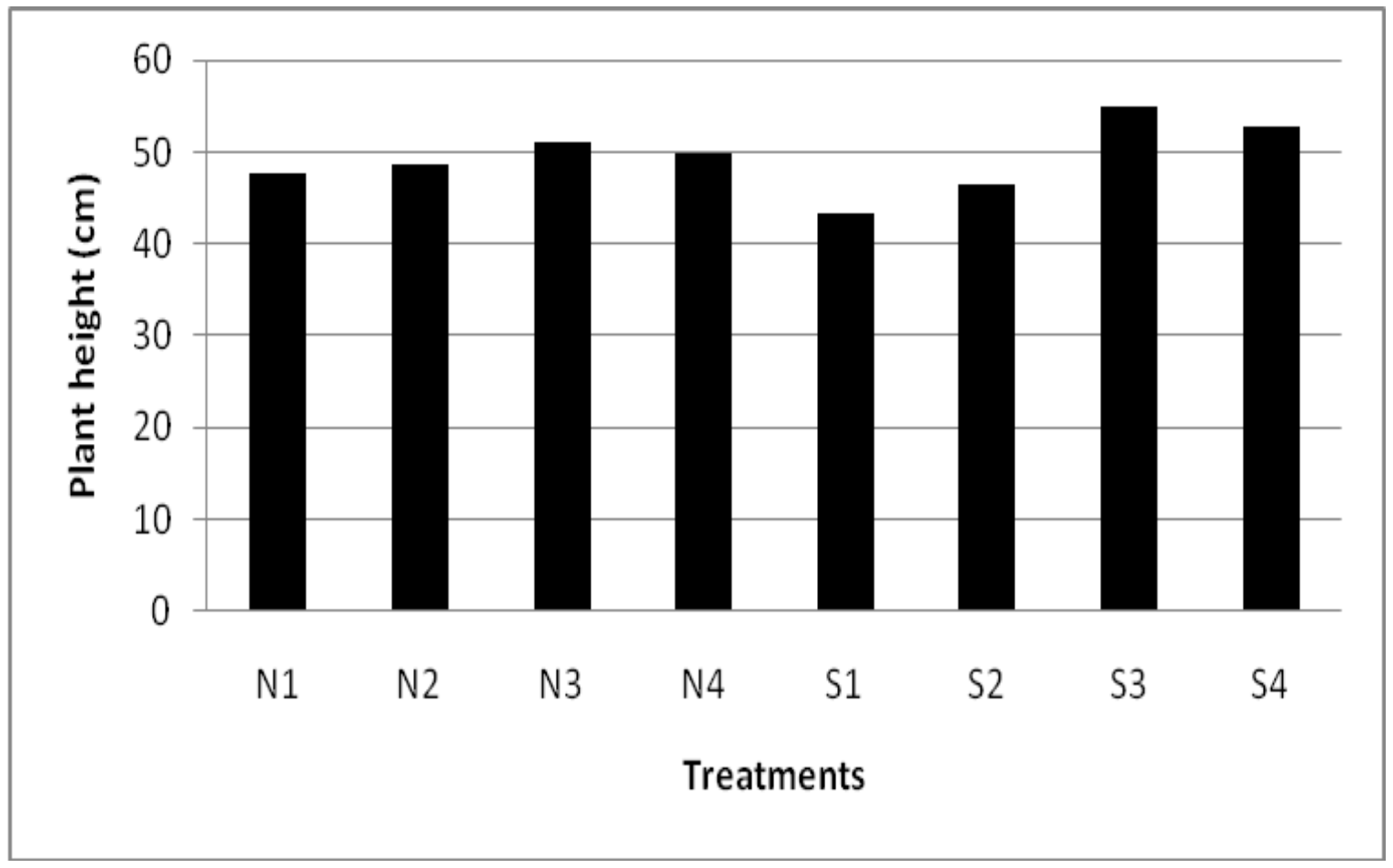


Fig.3 Effect of nitrogen and sulphur on number of leaves per plant

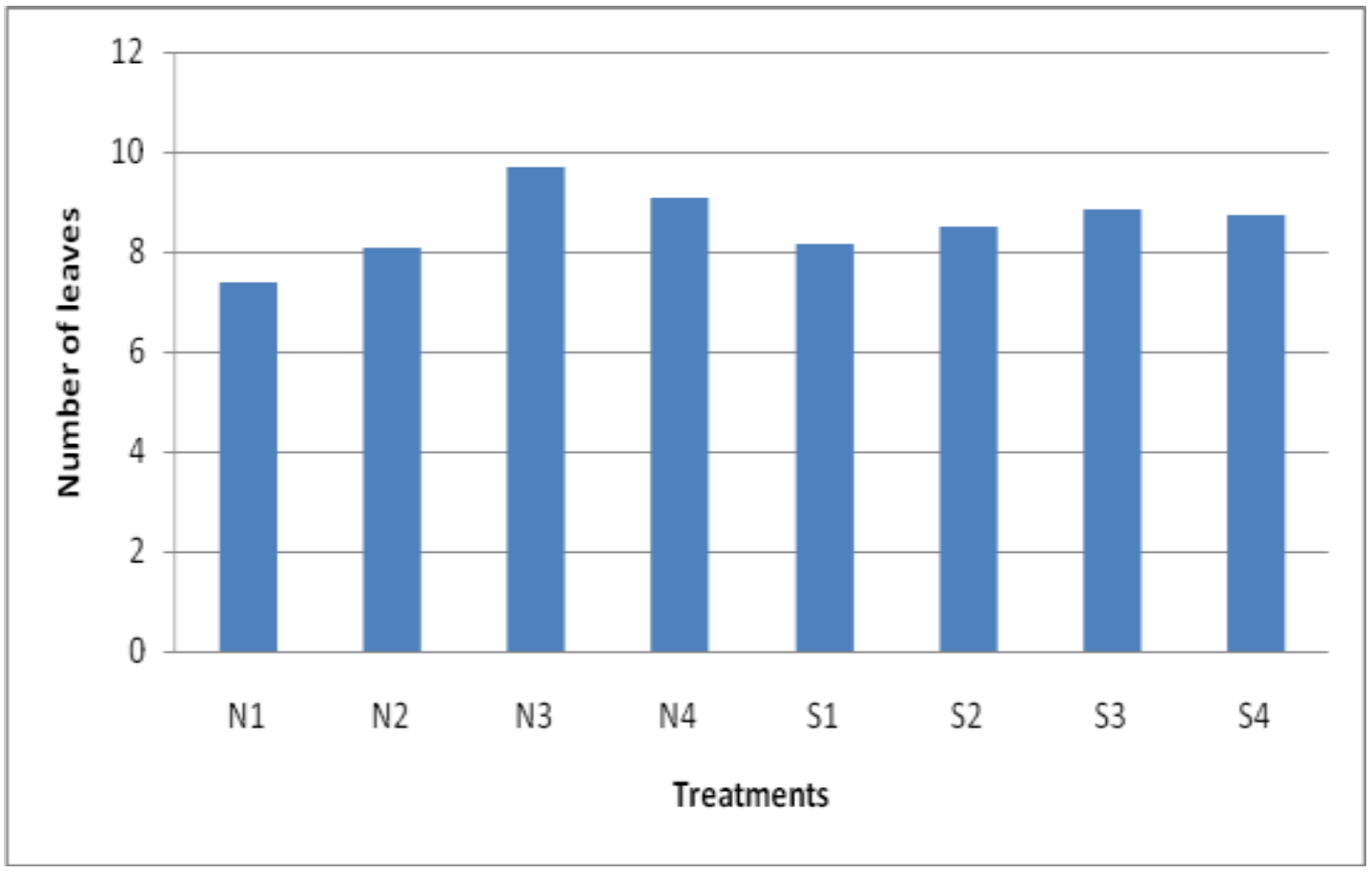

Fig.4 Effect of nitrogen and sulphur on yield per hectare (q)

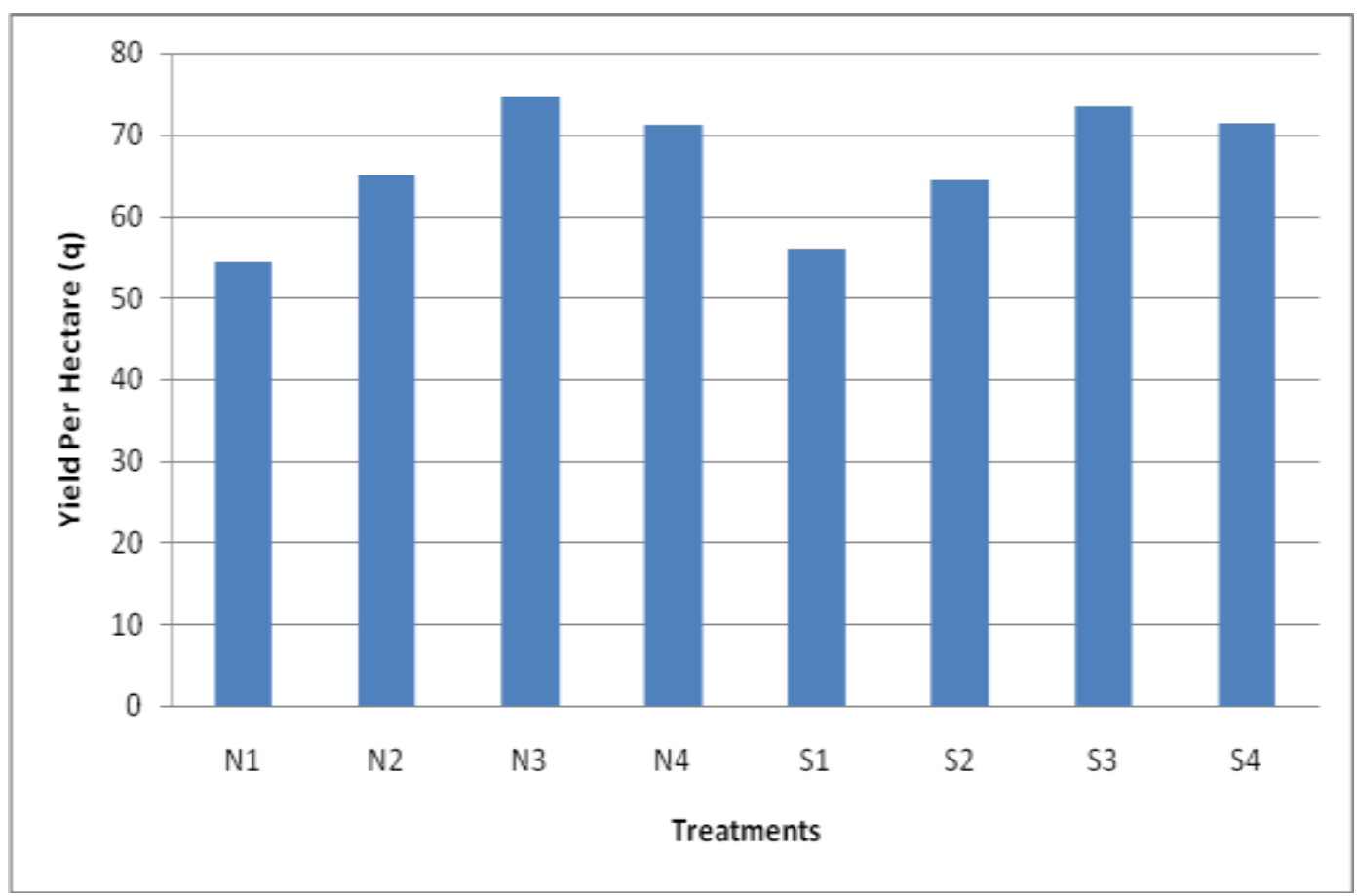


Sulphur level registered significant effect on yield. And it was found greater under $40 \mathrm{~kg}$ sulphur/ha (73.34 q).

\section{Effect of nitrogen}

Application of $100 \mathrm{~kg}$ nitrogen/ha producing maximum plant height, number of leaves and length of leaves over 125, 75 and $0 \mathrm{~kg}$ nitrogen/ha. Application of $100 \mathrm{~kg}$ nitrogen/ha produced highest yield of Garlic bulb over 125,75 and $0 \mathrm{~kg}$ nitrogen/ha.

\section{Effect of sulphur}

Application of $40 \mathrm{~kg}$ sulphur/ha increased all the growth parameter (plant height, number of leaves, length of leaves) of Garlic plant over 60, 20 and $0 \mathrm{~kg}$ sulphur/ha. Application of 40 $\mathrm{kg}$ sulphur/ha increased the total bulb yield of Garlic over 60, 20 and $0 \mathrm{~kg}$ sulphur/ha.

\section{References}

Anwar, M.N., Sarker, J.U., Rahman, M., Islam, M.A., Begum, M., 2001. Response of onion to nitrogen, phosphorus, potassium, sulphur and zinc. Bangladesh Journal of Environment Science 7, 68-72

Bertoni, G.; Morard, P.; Soubieille, C. and Llorens, J. M. (1992). Growth and nitrogen nutrition of Garlic (Allium sativum L.) during bulb development. Scientia Horticulturae. 50: 3, 187-195.

Ershadi, A.; Noori, M.; Dashti, F.; and Bayat, F. (2010). Effect of different nitrogen fertilizers on yield, Pungency and Nitrate accumulation in Garlic (Allium sativum L.) Acta Horticulturae. 853, 135-138.

Farooqui MA, Naruka IS, Rathore SS, Singh PP, Shaktawat RPS et al., Effect of nitrogen and sulphur levels on growth and yield of garlic (Allium sativum L.). FAOSTAT 2011 Food and Agriculture
Hore JK. Ghanti S, Chanchan M. Influence of nitrogen and sulphur nutrition on growth and yield of garlic (Allium sativum L.). Journal of Crop and Weed. 2014; 10(2): 14-18

Jaggi, R.C. and Dixit, S.P. (1999). Onion response to sulphur in representative vegetables growing soil of Kangra Valley of Himanchal. Journal of Elementology. 12 (3):pp. 395-506.

Janick, J. (1979). Horticulture Science, Freedom and Co. San Francisco, P. 544. Journal of the American Chemical Society, 66: 1950-1951

Lima, C. P.; de Bull, L. T.; Backes, C.; Godoy, L. J. G.; and Kiihl, T. A. M. (2008). Yield and quality of vernalized Garlic as affected by nitrogen rates. Cientifica (Jaboticabal). 36: 1, 48-55.

Magray M. Mudasir, Chattoo. M.A, Narayan. S, Najar, G.R, Jabeen Nayeema and Ahmad Tariq. Effect of sulphur and potassium applications on growth and chemical characteristics of garlic 2017. The Bioscan, 12(1):471-475.

Nagaich KN, Trivedi SK, Lekhi R. Effect of sulphur and potassium fertilisation in onionj (Allium cepa L). Hort. J., 1999; 12:25-31.

Panse VG, Sukhatme PU, Statistical Methods for Agricultural workers, ICAR, New Delhi, 1978.

Singh, P. K. and Singh, D. R.(2010). Effect of spacing and levels of nitrogen on growth and yield of Garlic. Indian Journal of Horticulture. 67: Special Issue, 305-307.

Tripathy, P., Sahoo, B.B., Priyadarshini, A., Das, S.K. and Dash, D.K. 2013. Effect of sources and levels of sulphur on growth, yield and bulb quality in onion (Allium cepa L.). International Journal of Bio-resources and Stress Management 4(4):641-644

Zaman, M.S., Hashem M.A., Jahiruddin M., \& Rahim M.A., (2011). Effect Of 
Nitrogen For Yield Maximization Of Garlic In Old Brahmaputra Flood Plain Soil. Bangladesh Journal of Agricultural Research, 36(2): 357-367. Zhou, Y., Wang D., Zhu, J., Liu, Q. \& Fan, M.X. (2005). The role of sulfur fertilizers in balanced fertilization. In:
L.J. De Kok and E. Schnug (eds.), Proceedings of the 1st Sino-German Workshop on Aspects of Sulfur Nutrition of Plants 23-27 May 2004 in Shenyang, China, Landbauforschung Völkenrode, Special Issue 283:171176.

\section{How to cite this article:}

Devesh Tiwari, Ajay kumar Gautam, Rohit Kumar and Sharad Sachan. 2019. Effect of Different Doses of Nitrogen and Sulphur on Growth and Yield of Garlic. Int.J.Curr.Microbiol.App.Sci. 8(10): 1601-1610. doi: https://doi.org/10.20546/ijcmas.2019.810.187 